\title{
A critical investigation into the antibiotic sterilization of heart valve homografts
}

\author{
P A MELA M . W A T ER W ORTH, EUNICE LOCKEY, \\ E. M. B E R R Y, a n d H E E N M . P E A R E \\ Departments of Microbiology, University College Hospital and National Heart Hospital, London
}

\begin{abstract}
Waterworth, Pamela M., Lockey, Eunice, Berry, E. M., and Pearce, Helen M. (1974). Thorax, 29, 432-436. A critical investigation into the antibiotic sterilization of heart valve homografts. Sterility tests of homograft heart valves sterilized by antibiotics were found to be invalidated by carry-over of the antibiotics. A method was devised to test the efficacy of different antibiotic mixtures using membrane filters. Fifty-five organisms, including 13 species, were tested, and sterility was achieved with only 35 .
\end{abstract}

Homograft heart valves were first used in clinical cardiac surgery to replace diseased aortic valves by Ross in 1962 .

Theoretically donor valves could be collected under sterile conditions, but in practice this is logistically impossible. Additionally, Yacoub and Kittle (1970) showed that heart blood obtained by sterile means from 45 refrigerated cadavers proved infected in $85 \%$. The commonest organisms were Escherichia coli and Streptococcus faecalis, but Klebsiella, Proteus, and Pseudomonas were well represented, together with a few staphylococci.

The earlier methods of sterilization included ethylene oxide, $\beta$-propriolactone, formalin, and gamma irradiation with or without flash-freezing and freeze-drying. The resultant valve was regarded as a skeletal framework into and over which it was hoped the host's tissues would grow. Hudson (1966), studying the freeze-dried valves sterilized by the ethylene oxide technique of Longmore, Lockey, Ross, and Pickering (1966), and Smith (1967), studying the freeze-dried valves sterilized by the $\beta$-propriolactone method of Rains et al. (1956) and kept in nutrient medium similar to that described by Gross, Bill, and Peirce (1949), showed that the cusps remained acellular and of ten tore or ruptured. Missen and Roberts (1970) also commented on the calcification and cusp rupture which could occur in such valves.

Barratt-Boyes and Roche (1969) first suggested the use of antibiotics as sterilizing agents in 1969 and since then many formulae, which their authors are continually trying to improve, have evolved (Lockey, Al-Janabi, Gonzalez-Lavin, and Ross, 1972; Angell, deLanerolle, and Shumway, 1973; Yacoub, personal communication). Nutrient media are now usually added to the antibiotic mixtures and some are further treated with dimethyl sulphoxide and stored at the temperature of liquid nitrogen. On the basis of autoradiography and tissue culture these valves are considered to contain living fibroblasts which can remould the valve structure and sustain long-term function (Kosek, Iben, Shumway, and Angell, 1969; Al-Janabi, Gonzalez-Lavin, Neirotti, and Ross, 1972). Recent work by Gavin, Henderson, Monroe, and Barratt-Boyes (1973) has suggested that histological changes in homograft valves are little different after either chemical or antibiotic methods of sterilization.

At the National Heart Hospital at least 305 valves which had been sterilized with antibiotics by the method of Lockey et al. were used between March 1971 and December 1973. All had been tested for sterility by placing pieces of aorta, approximately $2 \times 10 \mathrm{~mm}$, in the antibiotic solution with the homograft. After 24 hours' exposure these were removed and one piece was placed in each of $10 \mathrm{ml}$ of serum broth, Brewer's medium, and Sabouraud's medium. Subcultures were made after 24 and 72 hours' incubation and these were incubated at $37^{\circ} \mathrm{C}$ for up to five days. Nearly 500 homografts have now been tested by this method and all were apparently sterile. However, the isolation of a gentamicin-resistant Pseudomonas from a homograft valve at re-operation three months after implantation, together with 
increasing pressure from the surgeons to reduce the concentration of antibiotics used, led us to a critical evaluation of the whole technique.

\section{MATERIALS AND METHODS}

TESTS TO ILLUSTRATE CARRY-OVER OF ANTIBIOTIC ON VALVE TISSUE Pieces of aorta, approximately $2 \times 10 \mathrm{~mm}$, which had been exposed to solution $\mathbf{A}$ (see below) at $4^{\circ} \mathrm{C}$ for 24 hours were washed by agitation for 30 minutes in eight separate $100 \mathrm{ml}$ portions of physiological saline. They were then placed on blood agar plates, some seeded with the Oxford Staphylococcus aureus and others with Pseudomonas aeruginosa.

TESTS FOR ANTIBIOTIC EFFICACY AND CARRY-OVER Antibiotic solutions All antibiotics were prepared in sterile water and added to TC 199 medium containing $8 \mathrm{ml}$ calf serum and $8 \mathrm{ml} 4.4 \%$ sodium bicarbonate per $100 \mathrm{ml}$. In the later experiments the calf serum was reduced to $4 \mathrm{ml}$ in an attempt to increase bactericidal effect. The addition of aminoglycoside antibiotics reduced the pH to about 5.5 and this was corrected by the addition of $\mathrm{N} / 10$ sodium hydroxide until the colour of the indicator returned to its original.

\section{Antibiotic mixtures}

Solution A

(currently in use at

The National Heart Hospital)

$\begin{array}{lr}\text { Erythromycin } & 6,000 \mu \mathrm{g} / \mathrm{ml} \\ \text { Methicillin } & 10,000 \mu \mathrm{g} / \mathrm{ml} \\ \text { Gentamicin } & 4,000 \mu \mathrm{g} / \mathrm{ml} \\ \text { (Nystatin } & 2,500 \text { units } / \mathrm{ml} \text { ) }\end{array}$

Solution B

Penicillin

Neomycin

Polymyxin B sulphate $\quad 10 \mu \mathrm{g} / \mathrm{ml}$

(equals 100 units $\mathrm{ml}$ )

Solution C

Penicillin

Gentamicin

Polymyxin B sulphate

$$
\begin{array}{r}
1,000 \mu \mathrm{g} / \mathrm{ml} \\
1,000 \mu \mathrm{g} / \mathrm{ml} \\
10 \mu \mathrm{g} / \mathrm{ml}
\end{array}
$$

Test organisms These were recent clinical isolates and stock cultures with known antibiotic-resistance patterns. Two of the recent isolates were obtained from homografts before sterilization processes were begun and found to be gentamicin-resistant (Acinetobacter and Achromobacter).

METHOD Two drops of an overnight broth culture of the organism under test, diluted 1 in 10 in halfstrength peptone water, were added to $5 \mathrm{ml}$ of antibiotic solution. This was left for 24 hours at room temperature, and $2 \mathrm{ml}$ were then syringed through a Swinnex-25 filter followed by $25 \mathrm{ml}$ of sterile water.
The membrane was removed from the filter and cut with a sterile blade into two pieces, and both halves were placed in $20 \mathrm{ml}$ of nutrient broth (Oxoid No. 2). Cultures were kept at $37^{\circ} \mathrm{C}$ for three days.

If growth occurred the antibiotic combination was not effective and the identity of the organism was confirmed. If growth did not occur it was possible that inhibition was due to antibiotic carry-over. If the broth remained sterile therefore the tube was lightly re-inoculated with the test organism and re-incubated. If growth was still inhibited, sufficient carry-over of antibiotic had occurred to render the test of antibiotic efficacy invalid.

Counts of surviving organisms The test mixtures were filtered as described above. The membrane was then cut into four pieces, shaken well in $2 \mathrm{ml}$ of sterile water and $0.5 \mathrm{ml}$ of this and 1 in 10 and 1 in 100 dilutions made from it, and added to pour plates of nutrient agar (Oxoid blood agar base No. 2).

\section{RESULTS}

Even when fragments of antibiotic-treated aorta had been washed eight times, sufficient antibiotics were still present to diffuse into the surrounding medium and inhibit bacterial growth over a wide area. It was clear that the sterility tests previously used had been invalidated by carry-over of the antibiotic. It was therefore decided to attempt to prove the sterilizing efficacy of the antibiotic mixture by the method described above and thereafter dispense with sterility tests. It was originally hoped that it would be possible to cultivate the filter membrane on blood agar plates and thus see what proportion of the inoculum, if any, survived. Unfortunately sufficient antibiotic was absorbed onto the membrane to inhibit the growth of sensitive organisms. This was overcome by placing the membrane in $20 \mathrm{ml}$ of broth, but carry-over remained a hazard and all tests were checked for it. As nystatin is normally used as a fine suspension which would have precipitated on the filter, it was omitted from all tests with bacteria.

The first Gram-negative bacilli tested were the Acinetobacter and Achromobacter isolated from unsterilized homografts and known to be gentamicin-resistant. Large numbers of both survived treatment with solution $\mathrm{A}$, as did the strain of Alkaligenes later isolated from an implanted homograft.

There appeared to be several advantages in using polymyxin in a sterilizing mixture; it is highly and rapidly bactericidal, it acts on resting bacteria, and is active against both Acinetobacter and Achromobacter. It was obviously necessary to add an aminoglycoside for Providencia and 
Proteus species, and it was felt that neomycin shared with polymyxin the further advantage that neither would be required for clinical treatment. Penicillin was added for Gram-positive species. Unfortunately, there was considerable carry-over from this mixture (solution $B$ ). The results of tests with solutions A and B are given in Table I.

T A B L E I

RESULTS OF TESTS WITH SOLUTIONS A AND B

\begin{tabular}{l|cc} 
& \multicolumn{2}{|c}{ Solution } \\
\hline & A & B \\
\hline Achromobacter & + & + \\
Acinetobacter & + & + \\
Pr. rettgeri 131 & NT & + \\
Pr. rettgeri 579 & NT & + \\
Providencia 1 & NT & - \\
Providencia 29 & NT & - \\
S. maruginosa & NT & + \\
Staph. aureus 1 & NT & + \\
Staph. aureus 2 & NT & + \\
Alkaligenes & NT & NT \\
\hline
\end{tabular}

+ Growth from filter membrane after overnight incubation.

NT $=$ Not tested.

As nearly all the organisms tested with solution B were resistant to kanamycin and therefore neomycin it was not surprising that those which were also resistant to polymyxin survived. Neomycin was therefore replaced by gentamicin (solution C) and a wider range of organisms was tested. The results are given in Table II. The failure to kill any of the nine strains of Providencia was not altogether unexpected as this species is resistant to polymyxin and most of the strains were also resistant, or moderately so, to gentamicin. The

T A B L E I I

RESULTS OF EXPOSURE OF ORGANISMS TO SOLUTION C FOR 24 HOURS AT ROOM TEMPERATURE, THE FILTER MEMBRANE BEING CULTIVATED IN $20 \mathrm{ml}$ BROTH

\begin{tabular}{l|c|c|cc}
\hline \multicolumn{1}{c|}{ Organism } & $\begin{array}{c}\text { No. of } \\
\text { Strains }\end{array}$ & $\begin{array}{c}\text { No. } \\
\text { Sterilized }\end{array}$ & \multicolumn{2}{|c}{ Growth in } \\
\cline { 2 - 4 } & 7 & 6 & 0 & 3 day \\
\hline Staph. aureus & 7 & 1 & 3 & 3 \\
Str. faecalis & 6 & 5 & 0 & 1 \\
E. coli & 4 & 0 & 0 \\
Klebsiella spp. & 2 & 1 & 1 & 0 \\
Pr. mirabilis & 2 & 1 & 1 & 0 \\
Pr. morgani & 2 & 1 & 1 & 0 \\
Pr. rettgeri & 9 & 0 & 6 & 3 \\
Providencia & 4 & 4 & 0 & 0 \\
S. marsescens & 7 & 7 & 0 & 0 \\
Ps. aeruginosa & 1 & 1 & 0 & 0 \\
Achromobacter & 1 & 3 & 0 & 0 \\
Acinetobacter & 3 & 3 & 0 & 0 \\
\hline Alkaligenes & 55 & 35 & 12 & 8 \\
\hline Total tested & & & \\
\hline
\end{tabular}

Number of strains yielding no growth or growth after one or three days' incubation are shown. (Two strains of $E$. coli and one Klebsiella were inhibited by carry-over and are excluded from the Table). survival of six out of seven strains of Str. faecalis $\stackrel{.}{\Rightarrow}$ was much more disturbing. Some of these strains were re-tested with the period of exposure to theo drugs increased to three days, with the inoculum흘 reduced to one-tenth and one-hundredth of the $\frac{\bar{m}}{5}$ original, and with the penicillin increased to $\stackrel{\mathbb{}}{\varnothing}$ $5,000 \mu \mathrm{g} / \mathrm{ml}$ and the gentamicin to $2,000 \mu \mathrm{g} / \mathrm{ml}$. ळ All failed to eliminate the organism. In view of $\overrightarrow{ }$ the well-proven efficacy of penicillin and strepto-. mycin in the clinical treatment of Str. faecalis $\vec{\omega}$ endocarditis, these organisms were then tested $\stackrel{\circ}{\circ}$ with the gentamicin replaced by streptomycin, $\overrightarrow{\vec{x}}$ $10,000 \mu \mathrm{g} / \mathrm{ml}$; again all cultures grew overnight. i The addition of $1,000 \mu \mathrm{g} / \mathrm{ml}$ of erythromycin also allowed the growth of all four strains of Str.t faecalis tested.

An attempt was made to estimate the number응 of survivors, and the results of some of the countsmade on washings from membranes are given in $\subsetneq$ Table III. These suggest that with the majority< of organisms there is at least a $99.9 \%$ kill, but $\vec{\varphi}$ when the organism is highly resistant to genta- $\rightarrow$ micin as well as to polymyxin, the survival rate will be much higher. The bactericidal action of penicillin is greater at higher temperatures, and one strain of Str. faecalis was tested at $37^{\circ} \mathrm{C}$ as. well as at room temperature, with considerable improvement in performance (see Table III).

T A B L E I I I

NUMBER OF ORGANISMS RECOVERED FROM MEMBRANES AFTER EXPOSURE TO SOLUTION C FOR 24 HOURS

\begin{tabular}{|c|c|c|c|c|}
\hline \multirow{3}{*}{ Organism } & \multicolumn{3}{|c|}{$\begin{array}{l}\text { No. of Colonies from } 0.5 \mathrm{ml} \\
\text { Washings }\end{array}$} & \multirow{3}{*}{$\begin{array}{l}\text { Day on } \\
\text { which } \\
\text { Growth } \\
\text { appeared } \\
\text { in Broth } \\
\text { (Method 2) }\end{array}$} \\
\hline & \multirow[b]{2}{*}{ Undiluted } & \multicolumn{2}{|c|}{ Diluted } & \\
\hline & & 1 in 10 & 1 in 100 & \\
\hline $\begin{array}{l}\text { Pr. morgani } \\
\text { Providencia } 1 \\
\text { Providencia } 30 \\
\text { Providencia } 33 \\
\text { Staph. aureus } \\
\text { Str. faecalis Paris } \\
\text { Str. faecalis Paris }\end{array}$ & $\begin{array}{r}0 \\
5 \\
++ \\
24 \\
1 \\
51\end{array}$ & $\begin{array}{r}0 \\
1 \\
235 \\
4 \\
0 \\
6\end{array}$ & $\begin{array}{r}0 \\
0 \\
28 \\
1 \\
0 \\
1\end{array}$ & $\begin{array}{l}1 \\
1 \\
1 \\
1 \\
3 \\
1\end{array}$ \\
\hline $\begin{array}{l}\text { at } 37^{\circ} \mathrm{C} \\
\text { Str. faecalis D } 10\end{array}$ & $\begin{array}{l}\mathbf{0} \\
\mathbf{0}\end{array}$ & $\begin{array}{l}\mathbf{0} \\
\mathbf{0}\end{array}$ & $\begin{array}{l}0 \\
0\end{array}$ & $\begin{array}{l}3 \\
3\end{array}$ \\
\hline
\end{tabular}

A control suspension treated similarly at the time of inoculation yielded 124 colonies from $0.5 \mathrm{ml}$ of 1 in 1,000 dilution. This was $\omega$ approximately $5 \%$ of the number of organisms present in the originalo suspension.

Human embryonic fibroblasts (flow 2,000 line,, pass No. 19) were placed in solutions $A$ and $C$ and examined microscopically at intervals. There was considerable cell degeneration in solution A after $\overrightarrow{\mathbb{D}}$

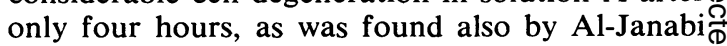
(personal communication), and total disruption after 24 hours. In contrast, the cells were 
apparently unaffected by 17 days' exposure to solution C. Solution A was retested using a less fragile cell line (HEp2) with similar results.

\section{DISCUSSION}

It is clear that routine sterility tests on homografts which have been exposed to high concentrations of antibiotics are misleading and a waste of time. It is therefore essential that if this method of sterilization is to be used it must be unfailingly bactericidal. Although the tests used here were stringent in that they demanded total sterility, it must also be accepted that a suspension of bacteria in a medium containing very little organic matter will be much more readily killed than bacteria embedded in pieces of tissue.

We consider solution $\mathrm{C}$ to be the most reliable of those tested, but even with this, sterility is unlikely to be achieved if the organism is highly resistant to polymyxin. With Gram-positive cocci and Proteus spp. the number of survivors may be small, but Providencia are commonly at least moderately resistant to gentamicin (Waterworth, 1972) and even the more sensitive strains used in this work were incompletely killed. Gentamicin actually performed little better than neomycin in the few tests in which the latter was used, but bacterial resistance to kanamycin, and therefore to neomycin, is more common than to gentamicin.

The survival of nearly all strains of Str. faecalis was disturbing, as was the inability to kill all strains of staphylococci. Penicillins only kill dividing organisms and for this reason all tests were done in nutrient medium at room temperature. It appears from these tests that gentamicin does not often kill the entire inoculum even when the organism is sensitive, and the survival of 'persisters' in penicillin is well recognized. This presumably explains the very small number of survivors from one out of seven strains of multiple-resistant Staph. aureus tested with solution C. It is clear that this mixture effectively kills Staph. aureus, but 'persisters' may occasionally survive; these are dormant cells which escape the action of penicillin because they are not dividing. As such they will be equally invulnerable to other penicillins and to increased concentrations of these drugs.

Small numbers of surviving organisms may well be killed by the host's defence mechanisms, but bacteriaemia is by no means uncommon after heart surgery (Lockey, Gonzalez-Lavin, Ray, and Chen, 1973) and in some, endocarditis ensues. It should be remembered that Gram-negative bacilli capable of surviving these antibiotic mixtures will be correspondingly difficult to treat if infection should occur. Many of those we have tested are uncommon as pathogens, but reports of endocarditis due to unusual organisms steadily increase in number. Since this work was begun we have isolated a strain of Alkaligenes from a homograft implanted three weeks earlier, and both this patient and the one referred to earlier died. It is true that these organisms may not have had their origin in the homografts themselves, but it is an unhappy coincidence that both were resistant to the sterilizing mixture.

It is difficult to see how efficacy can be improved and we do not think that antibiotics can be relied on to sterilize homograft tissues. The defence that they are less damaging to the grafts than other proven methods has already been questioned (Gavin et al., 1973). If antibiotics are to be used for this purpose, we recommend solution $\mathrm{C}$, to which 2,500 units per $\mathrm{ml}$ nystatin should be added.

We are very grateful to Mr. B. J. Mellars for the observations on tissue toxicity, and to Dr. E. Joan Stokes for much helpful discussion, both of The Department of Microbiology at University College Hospital.

We also wish to thank Mr. D. N. Ross and Dr. N. Al-Janabi, of the Homograft Department of the National Heart Hospital, for their co-operation and interest.

\section{REFERENCES}

Al-Janabi, N., Gonzalez-Lavin, L., Neirotti, R., and Ross, D. N. (1972). Viability of fresh aortic valve homografts-a quantitative assessment. Thorax, 27, 83.

Angell, W. W., deLanerolle, P., and Shumway, N. E. (1973). Valve replacement: present status of homograft valves. Progress in Cardiovascular Diseases, 15, 589.

Barratt-Boyes, B. G. and Roche, A. H. G. (1969). A review of aortic valve homografts over a six and one-half year period. Annals of Surgery, 170, 483.

Gavin, J. B., Henderson, P. B., Monroe, J. L., and Barratt-Boyes, B. G. (1973). Pathology of antibiotic-treated human heart valve allografts. Thorax, 28, 473.

Gross, R. E., Bill, A. H., Jnr., and Peirce, E. C. (1949). Methods for preservation and transplantation of arterial grafts. Surgery, Gynaecology and Obstetrics, 88, 689.

Hudson, R. E. B. (1966). Pathology of the human aortic valve homograft. British Heart Journal, 28, 291.

Kosek, J. C., Iben, A. B., Shumway, N. E., and Angell, W. W. (1969). Morphology of fresh heart valve homografts. Surgery, 66, 269. 
Lockey, E., Al-Janabi, N., Gonzalez-Lavin, L., and Ross, D. N. (1972). A method of sterilizing and preserving fresh allograft heart valves. Thorax, 27, 398.

- Gonzalez-Lavin, L., Ray, I., and Chen, R. (1973). Bacteraemia after open-heart surgery. Thorax, 28, 183.

Longmore, D. B., Lockey, E., Ross, D. N., and Pickering, B. N. (1966). The preparation of aorticvalve homografts. Lancet, 2, 463.

Missen, G. A. K. and Roberts, C. I. (1970). Calcification and cusp-rupture in human aortic-valve homografts sterilized by ethylene oxide and freeze-dried. Lancet, $2,962$.

Rains, A. T. H., Crawford, N., Sharpe, S. H., Shrewsbury, J. F. D., and Barson, G. J. (1956). Management of an artery-graft bank with special

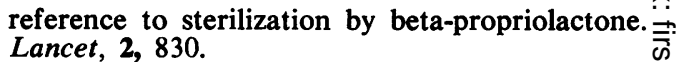

Ross, D. N. (1962). Homograft replacement of thet aortic valve. Lancet, 2, 487.

Smith, J. C. (1967). The pathology of human aortic valve homografts. Thorax, 22, 114.

Waterworth, P. M. (1972). The in-vitro activity of tobramycin compared with that of other amino-e glycosides. Journal of Clinical Pathology, 25, 979.

Yacoub, M. and Kittle, C. F. (1970). Sterilization of valve homografts by antibiotic solutions. Circula- $\vec{\omega}$ tion, 41 and 42, Supplement 2, 29.

Requests for reprints to: Dr. Eunice Lockey, Depart-i ment of Pathology, Barnet General Hospital, Well-@ house Lane, Barnet, Herts. 